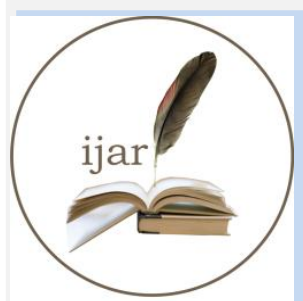

ISSN NO. 2320-5407

\section{Journal Homepage: - www.journalijar.com INTERNATIONAL JOURNAL OF ADVANCED RESEARCH (IJAR)}

Article DOI: $10.21474 / \mathrm{IJAR} 01 / 1429$

DOI URL: http://dx.doi.org/10.21474/IJAR01/1429
INTERNATIONAL JOURNAL OF ADVANCED RESEARCH (JSAR)

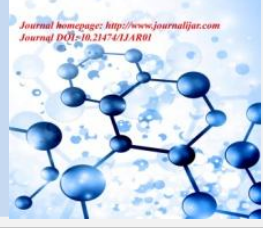

RESEARCH ARTICLE

\title{
NOTE ON AVAILABLE FEED FOR LIVESTOCK IN EASTERN SENEGAL AND UPPER SENEGAL RIVER BASIN.
}

\section{El Hadji Traore ${ }^{1 *}$, Moussa Camara ${ }^{1}$, Saliou Ngom $^{2}$, Cheikh Sall ${ }^{1}$, Cheikh Mbaye Boye ${ }^{1}$ et Adja Rokhaya} Diarra ${ }^{1}$.

1. Institut Senegalais de Recherches Agricoles- Laboratoire National de l'Elevage et de Recherches Veterinaires, BP 2057, Dakar, Senegal.

2. Institut Senegalais de Recherches Agricoles-Centre de Développement Horticole, BP3120 BP 3120, Dakar Senegal.

\section{Manuscript Info}

..........................

Manuscript History

Received: 12 June 2016

Final Accepted: 19 July 2016

Published: August 2016

Key words:-

Food, fodder, herbaceous, woody legume.

\section{Abstract}

Extensive farming in the Sahel is mainly limited by natural or humaninduced constraints. Aridity and over-exploitation of rangeland factors induces availability of feed resources for livestock.

Objectives:- this is a contribution note of livestock feed constraints, including: (i) identification of main constraints foranimal feeding in that area; (ii) assessing the amount of biomass produced and opportunities use of this characteristics pasture of Sahel region.

Method:- with herbaceous biomass sampling sheet and interviews with groups of farmers in the study area, it was possible to estimate the quantity and quality of forage grass available on natural pasture during the dry season.

Results:- biomass production hardly exceeds one ton per hectare in the dry season, averaging between 600 and $800 \mathrm{~kg} /$ ha consisting grasses mainly. Leguminous are available in small proportions such Zorniaglochidiata. Remarkable peak of biomass production are raised in the locality of Koundel with $1578.76 \mathrm{~kg} / \mathrm{ha}$ and about $1566 \mathrm{~kg} / \mathrm{ha}$ in Lescadie locality. On these pastures, the average of biomass is $1,063.03 \mathrm{~kg} / \mathrm{ha}$. Pasture capacity of the sites varies 4ha / UBT more than 10ha / UBT (UBT: Unitébétail tropical (Tropical Livestock Unit), is a theoreticalcattleweighing $250 \mathrm{~kg}$ ) with an average of $6,13 \mathrm{ha}$ / UBT. Herbaceous pasture is composed mainly of grasses.

Conclusion:- the pasture deficit noted, leads farmers to prune trees for animals feed; which contributes to the ecosystems degradation. Crop residues exist, but are undervalued. Producers need to be sensitized and trained to better use of crop residues.

Copy Right, IJAR, 2016,. All rights reserved.

\section{Introduction:-}

Ruminant feeding in Senegal, raises a very important issue, especially in extensive systems. Forages which are the main component of animals'diet come from rangeland. Now, these routes are exposed to various pressures, both 
natural (drought) and anthropogenic (bush fires, overexploitation ...). So thatrangelandproduction is affected, because as livestock land resource requirements are enormous(FAO, 2014).

Livestock in north-east part of Senegal is limited by many constraints that are primarily natural or human-induced hindering its development. In those constraints, livestock feed is prominently, especially in the dry seas on when pastures (main livestock feed sources) are experiencing a drastic decline in their production of forage biomass. This fact induce an animals' feed shortage situation, pushing farmers to increase pressure on natural resources and / or totranshumantin less hostile areas.

This study is a contribution to know livestock feed constraints Eastern Senegal and Upper Senegal River Basin. It has two specific objectives: (i) identify the main constraints that oppose good livestock feeding in eastern Senegal and Upper River Basin Senegal and practices develop by farmers to face and; (ii) assess the amount of biomass produced and opportunities for a best exploitation according the pasture load capacity for ruminants in thisspecific pasture of Sahel region.

\section{Materials and methods:-}

\section{Trials sites:-}

The sites are located in the Senegal River top Basin. They are divided between Tambacounda and Matam (see Figure 1). The vegetation a shrub steppetype, with a grass cover dominated by Aristidafuniculata and $A$. mitabilmowith a relatively large presence of ligneous, especially Combretum which is the dominant species in Boundouarea Others thornies species like Acacia seyal and Balanitesaegytiacaare met in the northern part (Bakel and Matam). The hydraulic system, exceptFaleme and Senegal rivers, is characterized by fossil valleys clogged in the rainy season (July-October) but dry up in the dry season.

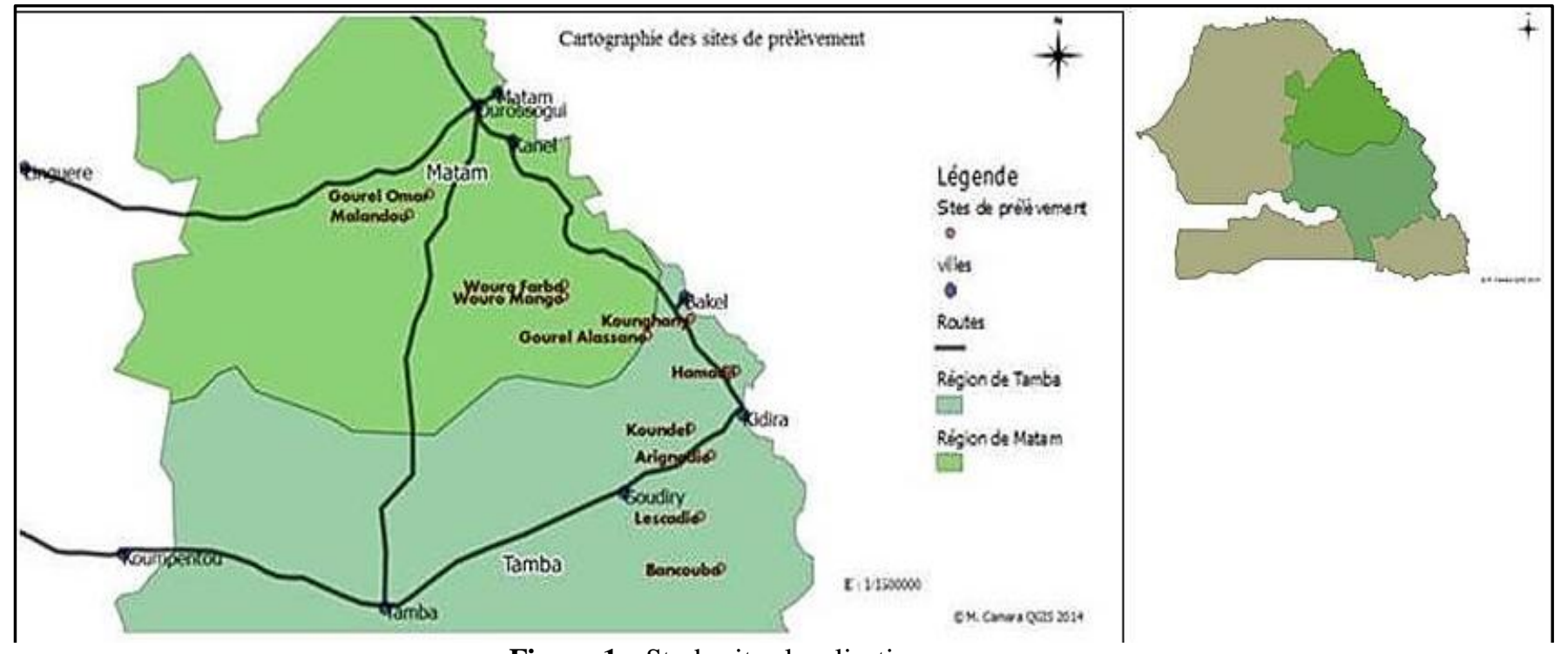

\section{Equipment:-}

Figure 1:- Study sites localisation.

The material used is composed of:

* A plot $1 \mathrm{~m}^{2}$ : it is a handmade wooden square of 1 meter square,

* A precision digital scale with a maximum range of $25 \mathrm{~kg}$

* An oven set at $60^{\circ} \mathrm{C}$.

\section{Sampling method and sample processing:-}

The estimation of biomass production was made by the method of full harvest (AKPO et al. 1993). This method involves cutting the herbaceous close to the ground in the plots located 5 times with $25 \mathrm{~m}$ intervals on a representative $1 \mathrm{~km}$ long of corridor route. The layout of the plots is random, the square is thrown randomly every 25 meters. The length of the corridor does not exceed $1 \mathrm{~km}$, but the sequence of sampling intervals shows the change in 
the type of substrate and grass cover on the same site. The number of samples varies from 1 to 5 according to the sites.

Samples are weighed, and then placed in an oven at a temperature of $60^{\circ} \mathrm{C}$ for 72 hours. After obtaining a constant weight due to loss of moisture, they were weighed again to determine the dry matter (DM) content.

Regarding the floristic composition, we relied on a previously formed from herbarium illustrated flora of Senegal (Berhaut, 1988) to identify the species that we have sorted manually. Species that could not be identified were classified by groups "other grasses"; legumes; timber. Finally, crop residues are classified as "straws". The weight of each species or group of species is then assessed in relation to the total weight of the sample. The charge capacity in UBT / ha / year was calculated by the formula:

$$
\mathbf{C C}(\text { ha } / \text { UBT } / \text { year })=\frac{\text { Feed need } / \text { UBT } / \text { year }}{\mathrm{BM} * \mathrm{CU}}
$$

With: BM: maximum biomass; UBT (TLU): Tropical Livestock Unit; CU: coefficient of utilization; CC = pastoral charge capacity.

\section{Recording of sociological data:-}

To collect sociological information, a focus groups interviews is conducted in 11 villages that are hosting biomass sampling sites. The questionnaire concerned animals rearing, feed resource use practices, conditions of access on feed. Part of the questionnaire also focused on the most used of ligneous in livestock feed, mode and operating period. In total, thirty people in nine villages were interviewed.

\section{Data processing:-}

The data were processed for a statistical processing (classifications, distributions ...) including crosstabs,by The Sphinx plussoftware.

\section{Results and Discussions:- \\ Pasture use:-}

The livestock feeding mode is predominantly extensive type,almostwithout complementation (less than $18 \%$ of the farmers surveyed do complementation). Therefore, animals' feeding is almost exclusively based on rangeland exploitation, already weakened by the lack of rainfall and the adverse effects of bushfires. It follows a shortage of cattle feeding, causing farmers to quite adopt a destructive behavior of their environment. During certain periods, crop residues are available in relatively abundant quantities in the sites. Their support contributes at least,to reduce the impact of feed shortages during a part of the year, but, again, the use of these residues is not rationally (almost feed straw consumed is not properly distribute and is penning by animalsduring the night). Many breeders are sedentary, they rear animals every day for a pasture and flocks back to the village for night. That's a time where animals drink and stay around the village and use harvested fields where residue can be exploited for feed.

The extensive systems of animals' rearing, exploit an itinerant pasture. According to their definition of extensive systems, SERE and STEINFELD (1995) argue that pastoral areas derive more than 90\% of the diet of livestock on natural pastures.Our observations in our study sites confirm this.Regarding ligneous, ICKOWICZ (1995) argues that only a part of the total biomass of leaf assessed is consumed by animals, it is the available volume. However, in case of pronounced deficit, the entire leaf biomass can be made available by the breeders who prune trees, contributing to further degradation of the ecosystem. This demonstrates the importance of ligneous in the diets of animals including small ruminants. Indeed according Traore (1998) ligneous trees participate in $90 \%$ goat diet, $70 \%$ for for sheep and $35 \%$ for cattle.

\section{Productivity of herbaceous biomass:-}

Due to bush fires occurred during the study, some sites like Bancouba were almost completely destroyed, not allowing any measure. Thus, of the 11 sites chosen initially, only 06 were able to provide enough sufficient biomass production to make significant sampling. Also, the site of Kounghany has not been sampling because it is in the bed of the Senegal River,a flood zone ofgilgai soil (clay microrelief formed by clay swelling following a hydration period). This kind of terrain does not promote the growth of herbaceous layer even it is characterized by a high density of Acacia nilotica. 


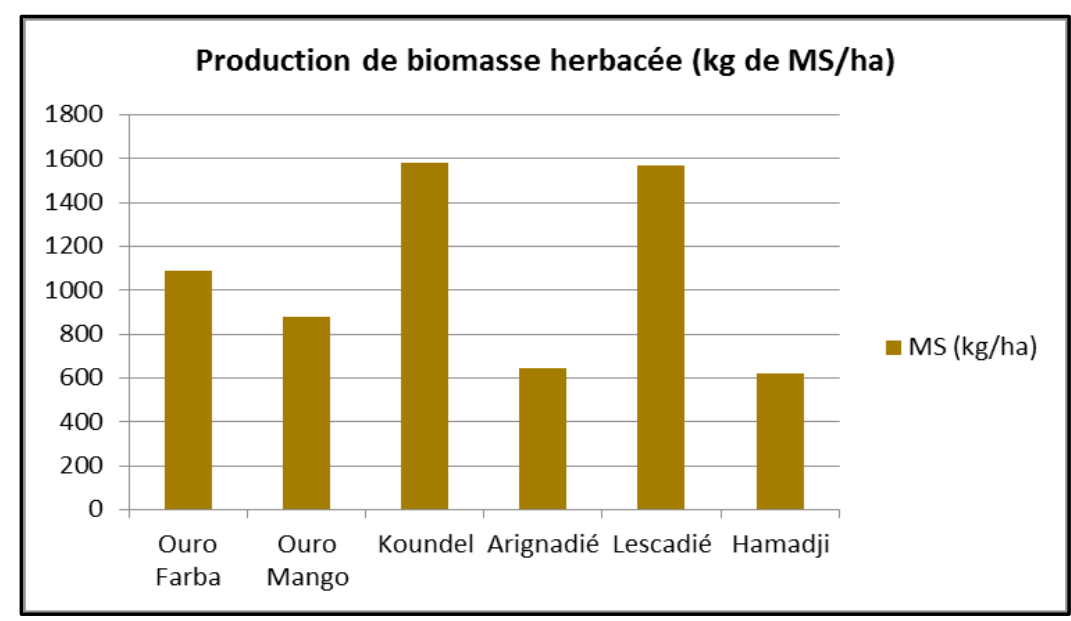

Figure 2:- Average production of biomass routes.

Of all the sites studied, biomass production hardly exceeds one ton per hectare in the dry season (Figure 2); the average being between 600 and $800 \mathrm{~kg} / \mathrm{ha}$, withgrasses compound essentially. Samples shows that it is common to find a few amounts of leguminouslikeZorniaglochidiata in dehydration state. This can be explained by the physiological state of the vegetation at this time of advanced drought. The prominent peaks for biomass production are to $1578.76 \mathrm{~kg} / \mathrm{ha}$ in the site ofKoundel and around $1566 \mathrm{~kg} /$ ha inLescadié site. On these pasture area, the average production of biomass is $1063.03 \mathrm{~kg} / \mathrm{ha}$.

The amounts of biomass evaluated on sites are consistent with those found in previous studies. GUERIN (1987) argues that $250 \mathrm{~kg} / \mathrm{ha}$ of herbaceous biomass are actually consumed by animals on a production of about $900 \mathrm{~kg} /$ ha of dry matter for all species in the lower Ferlo, meaning a consumption of $28 \%$. Also, FAO carried out a classification of drylands in which it characterizes the Sahel by plant biomass production of 1,000 kg of dry matter per hectare and a charge capacity of 7 ha / UBT, which is comparable to our study.

\section{Pasture herbaceous charge capacity:-}

The estimated production of pasture is used to calculate the charge capacity by using the ratio between the maximum production of biomass corrected by the duty cycle (35\%) and the needs of feed for anUBT. The charge capacity of rangeland sites studied (excluding other feed sources) varies from 4ha / UBT to more than 10ha / UBT, with an average of 6,13ha / UBT (Figure 3).

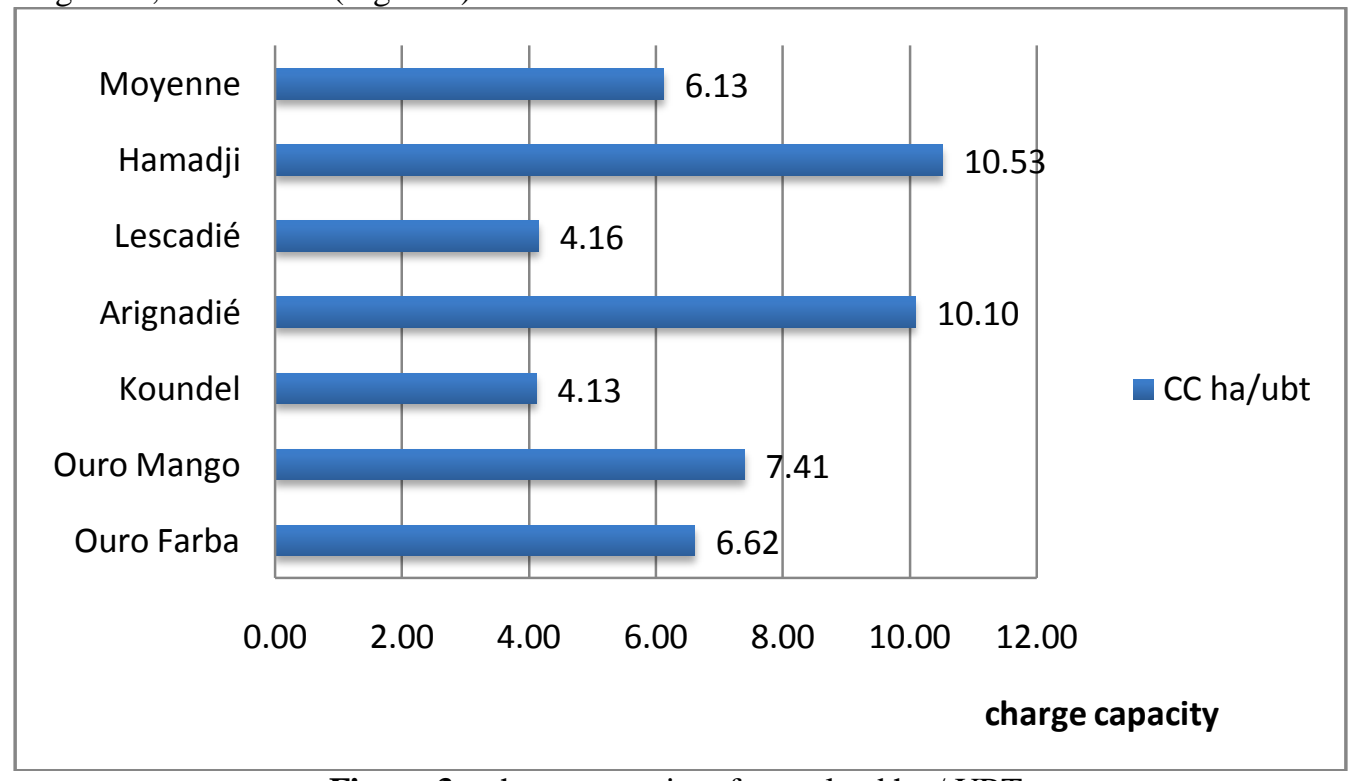

Figure 3:- charge capacity of rangeland ha / UBT. 
Herbaceous biomass deficit leadsfarmers to prune branches of trees to allow livestock to access it like feed, this situation brings all risks that come up (drought, soil vulnerability to erosion and fire, desertification ...). The importance of ligneous as source of nitrogenous and especially as the main animals' feed available in the dry season, make them subjected to unwanted cuts. Species such as Acacia seyal and Balanitesaegyptiaca(desert date), which are dominate trees in this landscape, are particularly palatable by ruminants. Sheep and goats are better able to eat the small bipinnatedleaves protected by thorns. Bohiniarufescensspecies, which maintains its greenery throughout the dry season, provides leaves and pods especially eaten by goats.

\section{Floristic composition of pasture:-}

The manual sorting of samples allowed us to identify many species (Table 1), despite the difficulty posed by identification of individuals species at this phenological stage. Nevertheless, it is possible to notice the recurrence of Aristidafuniculata whose dead individuals remain standing until late in the dry season. It represents $41 \%$ of species identified at Arignadié site then $11 \%$ and $13 \%$ respectively at Hamadji and Koundel sites. For sites where the sorting was heavily biased due to the disintegration of the biomass, we were still able to determine a presence of $A$. funiculata up 2.11\% atLescadié (Kidira area); $1.81 \%$ in OuroFarba and less than 1\% in Ouro Mango (Matam region). Other species of grasses as Aristidafuniculata, Schoenefeldiagracilis and Cenchrusbifoliorus met in low proportions. Finally, in the sorting of samples, leaves of some ligneous as Bosciasenegalensis and Combretummicratum were identified.

In general, the pasture compounds were essentially herbaceous grasses. However, it is common to find a few amounts of leguminouslike Zorniaglochidiata in a state of dehydration.The dominance of annual grasses in the dry season was mentioned by TOUTAIN and LHOSTE (1978). They argue that the carpet is arranged more or less continuous. "The straws up of these grasses are the main reserve of forage during 9 months of the dry season," they said.

Tableau 1:- répartition des espèces fourragères selon le site.

\begin{tabular}{|c|c|c|c|c|c|}
\hline Site & Species & Frequency & Site & Species & Frequency \\
\hline \multirow{8}{*}{$\begin{array}{l}\text { OuroFar } \\
\text { ba }\end{array}$} & A. funiculata & $1,81 \%$ & \multirow{8}{*}{ Ouro Mango } & A. mitabilmo & $0,10 \%$ \\
\hline & Z. glochidiata & $0,82 \%$ & & Z. glochidiata & $0,45 \%$ \\
\hline & C. bifoliorus & $1,27 \%$ & & A. funiculata & $0,65 \%$ \\
\hline & Ligneux & $7,04 \%$ & & S. gracilis & $0,01 \%$ \\
\hline & Autre herbacées & $7,34 \%$ & & Autre herbacées & $0,72 \%$ \\
\hline & Autres graminées & $40,03 \%$ & & Ligneux & $2,05 \%$ \\
\hline & Pailles & $41,69 \%$ & & Autres graminées & $22,60 \%$ \\
\hline & & & & Pailles & $73,41 \%$ \\
\hline Site & Species & Frequency & Site & Species & Frequency \\
\hline \multirow[t]{7}{*}{ Hamadji } & Autre graminées & $27,14 \%$ & \multirow[t]{5}{*}{ Arignadié } & Autres graminées & $13,18 \%$ \\
\hline & A. funiculata & $11,63 \%$ & & Pailles & $39,20 \%$ \\
\hline & Pailles & $59,70 \%$ & & Autre herbacées & $2,60 \%$ \\
\hline & Z. glochidiata & $0,08 \%$ & & Ligneux & $3,79 \%$ \\
\hline & Ligneux & $0,71 \%$ & & A. funiculata & $41,23 \%$ \\
\hline & S. gracilis & $0,22 \%$ & & & \\
\hline & Autre herbacées & $0,53 \%$ & & & \\
\hline
\end{tabular}

\section{Conclusion:-}

Herbaceous biomass production on rangelands upper Senegal basin varies by site, but remains low compared to the needs of the animals. This output is however, relatively stable over time. The degradation is becoming alarming in cases where overgrazing and pressure of human activities disrupt the balance between the environment and the total stocking. Indeed, the double exploitation (grazing and domestic uses) which are subjects' woody regeneration poses a problem.

The only biomass of course not enough to maintain the herd during the lean season. Thus we note long periods of food shortage, pushing farmers to go transhumance over long distances and long term. It also causes food shortages, loss of production and even cases of livestock mortality. It would then resort to other food sources such as crop 
residues, or rely on livestock backup operations (distribution of concentrated feed at subsidized prices). Cereal straws are available in relatively abundant but are not valued. This would disseminate improved processing techniques food value of these flaws.

\section{Reference:-}

1. AKPo L.E., GrouZis M. et Gaston A., 1993. Pluviosité et productivité des herbages de l'aire pastorale de WiiduThiengoli au Ferlo (Nord Sénégal) : Estimation des charges fréquentielles. Revue Elv. Méd. vét. Pays trop., $1993, \mathrm{pp}:$ 675-681.

2. GUERIN H., 1987.Alimentation des ruminants domestiques sur pâturages naturels sahéliens et sahélosoudaniens: Etude méthodologique dans la région du Ferlo au Sénégal, Thèse de Docteur-Ingénieur en Agronomie opt. Zootechnie ENSA-Montpellier, 211p.

3. Guerin H., Sall C., Friot D., Ahokpe B. et Ndoye A., 1985. Ebauche d'une méthodologie de diagnostic de l'alimentation des ruminants domestiques dans un système agropastoral : l'exemple de Thysse-KaymorSonkorong au Sénégal, Relations agriculture - élevage, Montpellier : 10 -13 septembre 1985, CIRAD, ISRA, $30 \mathrm{p}$.

4. ICKOWICZ A., 1995.Approche dynamique du bilan fourrager appliquée à des formations pastorales du Sahel tchadien, Thèse de doctorat de l'Université de Paris XII, UFR de Sciences, Spécialité Sciences de la vie et de la Santé, 472p.

5. SéRÉ C.etSteinfeld H. 1995, World Livestock Production Systems: Current Status, Issues and Trends, FAO, Animal Production And Health, 92p.

6. Toutain B. et Lhoste P., 1978.Essai d'estimation du Coefficient d'Utilisation de la biomasse herbacée par le bétail dans un périmètre sahélien, Rev. Elev. Méd. Vét. Pays trop., 1978, 31 : 95-101.

7. TraORE E. H., 1998. Facteurs de variations de la composition chimique et de la digestibilité des ligneux consommés par les ruminants domestiques au Sahel, Thèse doc. ${ }^{3 \mathrm{ème}}$ C. de Biol. Anim. FST/UCAD, 95p. 